\title{
Pengaruh Etos Kerja Dan Kompensasi Terhadap Komitmen Organisasi Pada DHL Logistic Di Jakarta
}

\author{
${ }^{1}$ Dodi Prasada, ${ }^{2}$ Denok Sunarsi, ${ }^{3}$ Arga Teriyan \\ Dosen Fakultas Ekonomi Universitas Pamulang \\ Email : ${ }^{1}$ dosen02454@unpam.ac.id, ${ }^{2}$ denoksunarsi@unpam.ac.id
}

\begin{abstract}
ABSTRAK
Penelitian ini bertujuan untuk mengetahui pengaruh etos kerja dan kompensasi terhadap komitmen organisasi pada DHL Logistic di Jakarta.

Metode yang digunakan adalah explanatory research dengan teknik analisis menggunakan analisis statistik dengan pengujian regresi, korelasi, determinasi dan uji hipotesis.

Hasil penelitian ini etos kerja berpengaruh signifikan terhadap komitmen organisasi sebesar 54,2\%, uji hipotesis diperoleh t hitung $>\mathrm{t}$ tabel atau (7,918 > 2,006). Kompensasi berpengaruh signifikan terhadap komitmen organisasi sebesar $43,3 \%$, uji hipotesis diperoleh $\mathrm{t}$ hitung $>\mathrm{t}$ tabel atau $(6,356>2,006)$. Etos kerja dan kompensasi secara simultan berpengaruh signifikan terhadap komitmen organisasi dengan persamaan regresi $\mathrm{Y}=8,221+0,435 \mathrm{X} 1+0,363 \mathrm{X} 2$ dan kontribusi pengaruh sebesar $62,8 \%$, uji hipotesis diperoleh $\mathrm{F}$ hitung $>\mathrm{F}$ tabel atau $(43,846>2,780)$.
\end{abstract}

Kata Kunci : Etos Kerja, Kompensasi, Komitmen Organisasi. 


\section{PENDAHULUAN}

Suatu organisasi atau perusahaan tentu memiliki karyawan yang dapat terpantau maupun tidak terpantau tergantung kondisi dan jumlahnya, perlu diadakannya komitmen organisasi sangatlah penting mengingat besar jumlah karyawan yang bekerja di perusahaan, kantor maupun instansi tersebut, agar dapat tercipta situasi yang di inginkan. Komitmen organisasi adalah sebagai suatu keadaan dimana seseorang karyawan memihak organisasi tertentu serta tujuan tujuan dan keinginannya untuk mempertahankan keanggotaan dalam organisasi tersebut.

Kompensasi menjadi salah satu kebutuhan utama yang dibutuhkan oleh seorang karyawan selaku manusia untuk memenuhi kebutuhan hidupnya. Kurniawan (2014) mendefinisikan kompensasi sebagai segala sesuatu yang diterima pekerja sebagai balas jasa atas kerja yang di berikannya kepada perusahaan. Pemberian kompensasi harus dilakukan secara adil dan merata agar tercipta lingkungan kerja yang kondusif dan produktif bagi perusahaan. Samudra (2014) menjelaskan kompensasi adalah hakhak pekerja yang harus diterima sebagai imbalan setelah menjalankan kewajibannya Kompensasi wajib diserahkan sesuai dengan kontribusi yang diberikan kepada perusahaan berupa bonus, subsidi dan kesejahteraan harus dimasukan ke dalam sistem membayar Acheampong. (2010).

Faktor etos kerja berkaitan pula dengan komitmen organisasi sebab kondisi komitmen organisasi yang baik dapat dipengaruhi oleh etos kerja yang baik pula, etos kerja sebagai batu loncatan dalam mencapai komitmen organisasi yang diinginkan, dalam kamus besar bahasa Indonesia etos kerja adalah semangat kerja yang menjadi ciri khas dan keyakinan seseorang atau suatu kelompok. Indikator etos kerja yang profesional menurut Sinamo (2011) antara lain: Kerja adalah rahmat, harus bekerja tulus penuh syukur. Kerja adalah amanah, harus bekerja penuh dengan integritas. Kerja adalah panggilan, harus bekerja tuntas penuh dengan tanggung jawab. Kerja adalah aktualisasi, harus bekerja penuh semangat. Kerja adalah ibadah, harus bekerja serius dengan penuh pengabdian. Kerja adalah seni, harus bekerja kreatif penuh suka cita. Kerja adalah kehormatan, harus bekerja unggul penuh dengan ketekunan. Kerja adalah pelayanan, harus bekerja sempurna penuh kerendahan hati.

Faktor lain yang mempengaruhi komitmen organisasi yaitu kompensasi. Konpensasi terbagi menjadi 2 (dua) yaitu kompensasi finansial (financial compensation) dan kompensasi non-finansisal (nonfinancial compensation), dimana kompensasi finansial terbagi lagi menjadi 2 (dua) bagian yaitu kompensasi langsung (direct financial compensation) berupa gaji atau upah, dan kompensasi tidak lagsung (indirect financial compensation) berupa tunjangan, dan kompensasi non-financial dalam bentuk insentif dan fasilitas Andico dkk. (2013) rendahnya komitmen karyawan disebabkan oleh pemberian insentif yang selalu tidak tepat waktu yang berdampak terhadap komitmen karyawan pada organisasinya 
Dari uraian latar belakang permasalahan, maka masalah yang diteliti selanjutnya dapat dirumuskan sebagai berikut :

1. Adakah pengaruh antara etos kerja terhadap komitmen organisasi pada DHL Logistic di Jakarta?

2. Adakah pengaruh antara kompensasi terhadap komitmen organisasi pada DHL Logistic di Jakarta?

3. Adakah pengaruh secara simultan antara etos kerja dan kompensasi terhadap komitmen organisasi pada DHL Logistic di Jakarta?

\section{KAJIAN TEORI ETOS KERJA}

Etos kerja sangat penting bagi perusahaan sebab dengan etos kerja yang tinggi diharapkan pekerja akan bekerja engan efektif dan efisien. Menurut Nitisemito Nitisemito (2017) berpendapat "Etos kerja adalah melakukan kegiatan atau pekerjaan secara lebih giat, sehingga hasil yang diperoleh menjadi baik. Sedangkan kegairahan kerja merupakan kesenangan yang mendalam terhadap pekerjaan yang dilakukan, oleh karena itu semangat kerja dengan integrasi dan iklim organisasi sulit untuk dipisahkan.

\section{KOMPENSASI}

Besarnya

kompensasi mencerminkan status, pengakuan, dan tingkat pemenuhan kebutuhan yang dinikmati oleh karyawan bersama keluarganya. Menurut Simamora (2014) menjelaskan bahwa "Kompensasi adalah semua pemberian perusahaan kepada karyawan sebagai imbalan atau balas jasa atas jasa yang diberikan karyawan kepada perusahaan.

\section{KOMITMEN ORGANISASI}

Komitmen organisasional bisa tumbuh disebabkan karena individu memiliki ikatan emosional terhadap perusahaan yang meliputi dukungan moral dan menerima nilai yang ada di dalam perusahaan serta tekad dari dalam diri untuk mengabdi pada perusahaan. Menurut Windy dan Gunasti (2012) "Pengertian komitmen organisasi menurut Mathins dan Jackshon adalah derajat dimana karyawan mempercayai dan menerima tujuan-tujuan organisasi serta tidak akan meninggalkan organisasi tersebut.

\section{METODE PENELITIAN}

Populasi dalam penelitian ini berjumlah 55 responden DHL Logistic di Jakarta. Sampel dalam penelitian ini berjumlah 55 responden. Jenis penelitian yang dipakai adalah asosiatif, dimana tujuannya adalah untuk mengetahui pengaruh antara variabel bebas terhadap variabel terikat baik parsial maupun simultan. Dalam menganalisis data digunakan uji instrumen, uji asumsi klasik, regresi, koefisien determinasi dan uji hipotesis..

\section{HASIL PENELITIAN DAN PEMBAHASAN}

\section{Analisis Deskriptif}

Pada pengujian ini digunakan untuk mengetahui skor minimum dan maksimum, mean score dan standar deviasi dari masing-masing variabel. Adapun hasilnya sebagai berikut: 
Tabel 1. Hasil Analisis Descriptive Statistics

Descriptive Statistics

\begin{tabular}{l|l|l|l|l}
$\mathrm{N}$ & Minimum & Maximum & Mean & Std. Deviation
\end{tabular}

\begin{tabular}{|l|r|r|r|r|r|}
\hline Etos kerja (X1) & 55 & 30 & 48 & 37.13 & 4.489 \\
\hline Kompensasi (X2) & 55 & 28 & 48 & 37.45 & 3.568 \\
\hline $\begin{array}{l}\text { Komitmen organisasi } \\
\text { (Y) }\end{array}$ & 55 & 32 & 48 & 37.98 & 3.649 \\
\hline Valid N (listwise) & 55 & & & & \\
\hline
\end{tabular}

Etos kerja diperoleh varians minimum sebesar 30 dan varians maximum 48 dengan mean score sebesar 37,13 dengan standar deviasi 4,489. Kompensasi diperoleh varians minimum sebesar 28 dan varians maximum 48 dengan mean score sebesar 37,45 dengan standar deviasi 3,568. Komitmen organisasi diperoleh varians minimum sebesar 32 dan varians maximum 48 dengan mean score sebesar 37,98 dengan standar deviasi 3,649.
2. Analisis Verifikatif.

Pada analisis ini dimaksudkan untuk mengetahui pengaruh variabel independen terhadap variabel dependen. Adapun hasil pengujian sebagai berikut:

\section{a. Analisis Regresi Linier} Berganda

Uji regresi ini dimaksudkan untuk mengetahui perubahan variabel dependen jika variabel independen mengalami perubahan. Adapun hasil pengujiannya sebagai berikut: Coefficients $^{\mathrm{a}}$

Tabel 2. Hasil Pengujian Regresi Linier Berganda.

\begin{tabular}{lllll|l|l} 
& \multicolumn{2}{l|}{$\begin{array}{l}\text { Unstandardized } \\
\text { Coefficients } \\
\text { Model }\end{array}$} & $\begin{array}{l}\text { Standardized } \\
\text { Coefficients }\end{array}$ & & \\
\hline 1 B & Std. Error & Beta & t & Sig. \\
\hline (Constant) & 8.221 & 3.370 & & 2.439 & .018 \\
\hline Etos kerja (X1) & .435 & .083 & .535 & 5.222 & .000 \\
\hline Kompensasi (X2) & .363 & .105 & .355 & 3.463 & .001 \\
\hline
\end{tabular}

a. Dependent Variable: Komitmen organisasi (Y)

Berdasarkan hasil pengujian pada tabel di atas, diperoleh persamaan regresi $\mathrm{Y}=8,221+0,435 \mathrm{X} 1+$ $0,363 X 2$. Dari persamaan tersebut dijelaskan sebagai berikut:

1) Konstanta sebesar 8,221 diartikan jika etos kerja dan kompensasi tidak ada, maka telah terdapat nilai komitmen organisasi sebesar 8,221 point.

2) Koefisien regresi etos kerja sebesar 0,435 , angka ini positif artinya setiap ada peningkatan etos kerja sebesar 0,435 maka komitmen organisasi juga akan mengalami peningkatan sebesar 0,435 point.

3) Koefisien regresi kompensasi sebesar 0,363, angka ini positif artinya setiap ada peningkatan kompensasi sebesar 0,363 maka komitmen organisasi juga akan mengalami peningkatan sebesar 0,363 point

\section{b. Analisis Koefisien Korelasi}

Analisis koefisien korelasi dimaksudkan untuk mengetahui 
tingkt kekuatan hubungan dari variabel independen terhadap variabel dependen baik secara Tabel 3. Hasil Pengujian Koefisien Korelasi Etos kerja Terhadap Komitmen Correlations $^{b}$

\begin{tabular}{|c|c|c|c|}
\hline \multicolumn{4}{|l|}{ Correlations $^{b}$} \\
\hline & & $\begin{array}{l}\text { Etos kerja } \\
(\mathrm{X} 1)\end{array}$ & $\begin{array}{l}\text { Komitmen } \\
\text { organisasi (Y) }\end{array}$ \\
\hline \multirow[t]{2}{*}{ Etos kerja (X1) } & $\begin{array}{l}\text { Pearson } \\
\text { Correlation }\end{array}$ & 1 & $.736^{* *}$ \\
\hline & Sig. (2-tailed) & & .000 \\
\hline \multirow[t]{2}{*}{$\begin{array}{l}\text { Komitmen } \\
\text { organisasi (Y) }\end{array}$} & $\begin{array}{l}\text { Pearson } \\
\text { Correlation }\end{array}$ & $.736^{* *}$ & 1 \\
\hline & Sig. (2-tailed) & .000 & \\
\hline
\end{tabular}

parsial maupun simultan. Adapun hasil pengujian sebagai berikut:

$\begin{array}{ccl}\text { Berdasarkan } & \text { hasil } & \text { etos kerja memiliki hubungan } \\ \text { pengujian diperoleh } & \text { nilai } & \text { yang kuat terhadap komitmen } \\ \text { korelasi sebesar } 0,736 \text { artinya } & \text { organisasi. }\end{array}$

Tabel 4. Hasil Pengujian Koefisien Korelasi Kompensasi Terhadap

\section{Correlations $^{b}$}

Komitmen organisasi

\begin{tabular}{lll|l} 
& & $\begin{array}{l}\text { Kompensasi } \\
(\mathrm{X} 2)\end{array}$ & $\begin{array}{l}\text { Komitmen } \\
\text { organisasi (Y) }\end{array}$ \\
\hline Kompensasi (X2) & $\begin{array}{l}\text { Pearson } \\
\text { Correlation }\end{array}$ & 1 & $.658^{* *}$ \\
\cline { 2 - 4 } & Sig. (2-tailed) & & .000 \\
\hline $\begin{array}{l}\text { Komitmen } \\
\text { organisasi (Y) }\end{array}$ & $\begin{array}{l}\text { Pearson } \\
\text { Correlation }\end{array}$ & $.658^{* *}$ & 1 \\
\cline { 2 - 4 } & Sig. (2-tailed) & .000 & \\
\hline
\end{tabular}

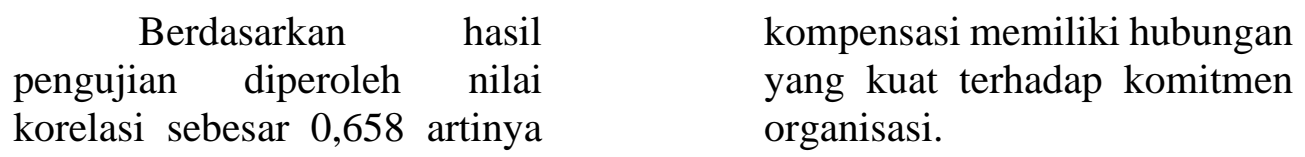

Tabel 6. Hasil Pengujian Koefisien Korelasi Etos kerja dan Kompensasi secara simultan Terhadap Komitmen organisasi Model Summary

\begin{tabular}{|c|c|c|c|c|}
\hline Model & $\mathbf{R}$ & R Square & $\begin{array}{l}\text { Adjusted } \\
\text { Square }\end{array}$ & $\begin{array}{l}\text { RStd. Error of the } \\
\text { Estimate }\end{array}$ \\
\hline 1 & $.792^{\mathrm{a}}$ & .628 & .613 & 2.269 \\
\hline
\end{tabular}

a. Predictors: (Constant), Kompensasi (X2), Etos kerja (X1)

Berdasarkan hasil pengujian diperoleh nilai korelasi sebesar 0,792 artinya etos kerja dan kompensasi secara simultan memiliki hubungan yang kuat terhadap komitmen organisasi 


\section{c. Analisis Koefisien Determinasi}

Analisis koefisien determinasi dimaksudkan untuk mengetahui besarnya persentase pengaruh dari variabel

Tabel 7. Hasil Pengujian Koefisien Determinasi Etos kerja Terhadap Komitmen organisasi.

\section{Model Summary}

\begin{tabular}{|c|c|c|c|c|}
\hline Mod & $\mathrm{R}$ & R Square & $\begin{array}{l}\text { Adjusted } \\
\text { Square }\end{array}$ & $\begin{array}{l}\text { RStd. Error of the } \\
\text { Estimate }\end{array}$ \\
\hline 1 & $.736^{\mathrm{a}}$ & .542 & .533 & 2.493 \\
\hline
\end{tabular}

independen terhadap variabel dependen baik secara parsial maupun simultan. Adapun hasil pengujian sebagai berikut.

a. Predictors: (Constant), Etos kerja (X1)

$\begin{array}{ccl}\text { Berdasarkan } & \text { hasil } & \text { etos kerja memiliki kontribusi } \\ \text { pengujian diperoleh nilai } & \text { pengaruh sebesar 54,2\% terhadap } \\ \text { determinasi sebesar 0,542 artinya } & \text { komitmen organisasi. }\end{array}$

Tabel 8. Hasil Pengujian Koefisien Determinasi Kompensasi Terhadap Komitmen organisasi.

\section{Model Summary}

\begin{tabular}{lllll} 
Model & $\mathrm{R}$ & R Square & $\begin{array}{l}\text { Adjusted } \\
\text { Square }\end{array}$ & $\begin{array}{c}\text { RStd. Error of the } \\
\text { Estimate }\end{array}$ \\
\hline 1 & $.658^{\mathrm{a}}$ & .433 & .422 & 2.774 \\
\hline
\end{tabular}

a. Predictors: (Constant), Kompensasi (X2)

\begin{tabular}{lccl}
\multicolumn{2}{c}{ Berdasarkan } & hasil & kontribusi pengaruh sebesar \\
pengujian diperoleh & nilai & $43,3 \%$ terhadap komitmen \\
determinasi & sebesar & 0,433 & organisasi.
\end{tabular}

artinya kompensasi memiliki

Tabel 9. Hasil Pengujian Koefisien Determinasi Etos kerja dan

Kompensasi Terhadap Komitmen organisasi

Model Summary

\begin{tabular}{lllll} 
Model $\mathrm{R}$ & R Square & $\begin{array}{l}\text { Adjusted } \\
\text { Square }\end{array}$ & $\begin{array}{l}\text { RStd. Error of the } \\
\text { Estimate }\end{array}$ \\
\hline 1 & $.792^{\mathrm{a}}$ & .628 & .613 & 2.269 \\
\hline a. Predictors: (Constant), Kompensasi (X2), Etos kerja (X1)
\end{tabular}

\begin{tabular}{lrr}
\multicolumn{2}{c}{ Berdasarkan } & hasil \\
pengujian diperoleh & nilai \\
determinasi sebesar & 0,628 \\
artinya etos kerja dan & dan \\
kompensasi secara simultan \\
memiliki kontribusi pengaruh \\
sebesar $62,8 \%$ terhadap \\
komitmen r organisasi, \\
sedangkan sisanya sebesar \\
$37,2 \%$ dipengaruhi faktor lain
\end{tabular}

d. Uji Hipotesis

Uji hipotesis Parsial (Uji t)

Pengujian hipotesis dengan uji $\mathrm{t}$ digunakan untuk mengetahui hipotesis parsial mana yang diterima. Hipotesis pertama: Terdapat pengaruh yang signifikan antara etos kerja terhadap komitmen organisasi. 
Tabel 10. Hasil Uji Hipotesis Etos kerja Terhadap Komitmen organisasi.

Coefficients $^{\mathbf{a}}$

\begin{tabular}{llllll|l} 
& \multicolumn{2}{c}{ Unstandardized } & \multicolumn{2}{l}{$\begin{array}{l}\text { Standardized } \\
\text { Coefficients }\end{array}$} & & \\
Model & B & Std. Error & Beta & t & Sig. \\
\hline 1 & (Constant) & 15.765 & 2.826 & & 5.579 & .000 \\
\hline & Etos kerja (X1) & .598 & .076 & .736 & 7.918 & .000 \\
\hline
\end{tabular}

a. Dependent Variable: Komitmen organisasi (Y)

tabel atau $(7,918>2,006)$, dengan demikian hipotesis pertama yang diajukan bahwa terdapat pengaruh yang signifikan atara etos kerja terhadap komitmen organisasi diterima.

Tabel 11. Hasil Uji Hipotesis Kompensasi Terhadap Komitmen organisasi.

\section{Coefficients $^{\mathrm{a}}$}

\begin{tabular}{lllll|ll} 
& \multicolumn{2}{l|}{$\begin{array}{l}\text { Unstandardized } \\
\text { Coefficients }\end{array}$} & \multicolumn{2}{l}{$\begin{array}{l}\text { Standardized } \\
\text { Coefficients }\end{array}$} & & \\
Model & B & Std. Error & Beta & t & \multicolumn{1}{l}{ Sig. } \\
\hline 1 & (Constant) & 12.793 & 3.980 & & 3.214 & .002 \\
\hline & Kompensasi (X2) & .673 & .106 & .658 & 6.356 & .000 \\
\hline
\end{tabular}

a. Dependent Variable: Komitmen organisasi (Y)

Berdasarkan hasil pengujian pada tabel di atas, diperoleh nilai $\mathrm{t}$ hitung > t tabel atau $(6,356>2,006)$, dengan demikian hipotesis kedua yang diajukan bahwa terdapat pengaruh yang signifikan atara kompensasi terhadap komitmen organisasi diterima.

\section{Uji Hipotesis Simultan (Uji F)}

Pengujian hipotesis dengan uji $\mathrm{F}$ digunakan untuk mengetahui hipotesis simultan yang mana yang diterima.

Hipotesis ketiga Terdapat pengaruh yang signifikan antara etos kerja dan kompensasi terhadap komitmen organisasi.

Tabel 12. Hasil Uji Hipotesis Etos kerja dan Kompensasi Terhadap Komitmen organisasi.

$\begin{aligned} & \text { ANOVA } \\
& \text { Model }\end{aligned}$
\begin{tabular}{lllllll} 
& & & & & \\
\hline 1 & Regression & 451.343 & 2 & 225.671 & 43.846 & $.000^{\mathrm{b}}$ \\
\cline { 2 - 6 } & Residual & 267.639 & 52 & 5.147 & & \\
\hline & Total & 718.982 & 54 & & & \\
\hline
\end{tabular}

Berdasarkan hasil pengujian pada tabel di atas, diperoleh nilai $\mathrm{F}$ hitung > F tabel atau (43,846> 2,780), dengan demikian hipotesis ketiga yang diajukan bahwa terdapat pengaruh yang signifikan atara etos kerja dan kompensasi terhadap komitmen organisasi diterima.

PEMBAHASAN

PENELITIAN

1. Pengaruh Etos kerja Terhadap Komitmen organisasi 
Etos kerja berpengaruh signifikan terhadap komitmen organisasi dengan korelasi sebesar 0,736 atau memiliki hubungan yang kuat dengan kontribusi pengaruh sebesar $54,2 \%$. Pengujian hipotesis diperoleh nilai $\mathrm{t}$ hitung $>\mathrm{t}$ tabel atau $(7,918>2,006)$. Dengan demikian hipotesis pertama yang diajukan bahwa terdapat berpengaruh signifikan antara etos kerja terhadap komitmen organisasi diterima.

2. Pengaruh

Terhadap

organisasi

Kompensasi berpengaruh signifikan terhadap komitmen organisasi dengan korelasi sebesar 0,658 atau memiliki hubungan yang kuat dengan kontribusi pengaruh sebesar 43,3\%. Pengujian hipotesis diperoleh nilai $\mathrm{t}$ hitung $>\mathrm{t}$ tabel atau $(6,356>2,006)$. Dengan demikian hipotesis kedua yang diajukan bahwa terdapat berpengaruh signifikan antara kompensasi terhadap komitmen organisasi diterima.

\section{Pengaruh Etos kerja dan Kompensasi Terhadap Komitmen organisasi}

Etos kerja dan kompensasi berpengaruh signifikan terhadap komitmen organisasi dengan diperoleh persamaan regresi $\mathrm{Y}=$ $8,221+0,435 \mathrm{X} 1+0,363 \mathrm{X} 2$, nilai korelasi sebesar 0,792 atau memiliki hubungan yang kuat dengan kontribusi pengaruh sebesar $62,8 \%$ sedangkan sisanya sebesar $37,2 \%$ dipengaruhi faktor lain. Pengujian hipotesis diperoleh nilai $\mathrm{F}$ hitung $>\mathrm{F}$ tabel atau $(43,846>2,780)$. Dengan demikian hipotesis ketiga yang diajukan bahwa terdapat berpengaruh signifikan antara etos kerja dan kompensasi terhadap komitmen organisasi diterima.

\section{KESIMPULAN DAN SARAN}

\section{A. Kesimpulan}

a. Etos kerja berpengaruh signifikan terhadap komitmen organisasi dengan kontribusi pengaruh sebesar $54,2 \%$. Uji hipotesis diperoleh nilai $\mathrm{t}$ hitung $>\mathrm{t}$ tabel atau $(7,918>2,006)$.

b. Kompensasi berpengaruh signifikan terhadap komitmen organisasi dengan kontribusi pengaruh sebesar 43,3\%. Uji hipotesis diperoleh nilai $\mathrm{t}$ hitung $>\mathrm{t}$ tabel atau $(6,356>2,006)$.

c. Etos kerja dan kompensasi berpengaruh signifikan terhadap komitmen organisasi dengan kontribusi pengaruh sebesar $62,8 \%$ sedangkan sisanya sebesar $37,2 \%$ dipengaruhi faktor lain. Uji hipotesis diperoleh nilai $\mathrm{F}$ hitung $>\mathrm{F}$ tabel atau $(43,846>2,780)$.

\section{B. Saran}

a. Perusahaan harus menegakkan peraturan dengan baik sesuai dengan ketentuan yang berlaku guna menjamin pegawai diperlakukan dengan adil.

b. Perusahaan harus selalu memberikan semangat dan 
apresiasi yang layak untuk memastikan pegawai memiliki semangat kerja yang tinggi.

c. Kinerja perusahaan dapat ditingkatkan dengan memberdayakan pegawai dengan menegakkan peraturan yang baik dan pemberian kompensasi yang lebih inten lagi

\section{DAFTAR PUSTAKA}

Algifari. (2015). "Analisis Regresi untuk Bisnis dan Ekonomi". Yogyakarta: BPFE.

Arikunto, Suharsimi (2014). "Prosedur Penelitian Suatu Pendekatan Praktek". Jakarta: Rineka Cipta.

Edi Sutrisno (2016). Manajemen Sumber Daya Manusia. Jakarta: Prenadamedia Group.

Fandy Tjiptono (2017), Serivce Quality and Satisfiation. Jakarta: Edisi tiga. Andi.

Freddy Rangkuti (2016) Strategi Promosi Yang Kreatif, Edisi Pertama, Cetakan Pertama Jakarta: Gramedia Pustaka Utama

Freed Luthans (2016) Organizational Behavior, McGraw-Hill, New York.

Gerry Dessler (2016) Human Resources Management, Prenticehall, London: International Inc.

Griffin R.W., \& Ronald, J.E. (2003). Dasar-Dasar Pemasaran. Jakarta: Raja

Handoko (2016) Manajemen Personalia dan Sumberdaya Manusia. Yogyakarta: BPFE.
Hasibuan (2016) "Manajemen Sumber Daya Manusia”. Haji Masagung. Jakarta.

Henry Simamora (2005), Manajemen Sumber Daya Manusia, STIE YKPN Bandung.

Hurriyati, Ratih. 2015. Bauran Pemasaran dan Loyalitas Konsumen. Alfabeta, Bandung. Imam Ghozali (2017). "Aplikasi Analisis Multivariate Dengan Program SPSS”. Edisi Kelima. Semarang: Badan Penerbit Undip.

Istijanto (2014) "Riset Sumber Daya Manusia”. Jakarta: PT. Gramedia Pustaka

Jasmani, J. (2018). Pengaruh Kinerja Keuangan Terhadap Harga Saham (Analisis Pada Perusahaan Property dan Real Estate Yang Go Public di Bursa Efek Indonesia. Jurnal Akuntansi Indonesia, 12(2).

Jasmani, J. (2018). Pengaruh Kinerja Keuangan Terhadap Harga Saham (Analisis Pada Perusahaan Property dan Real Estate Yang Go Public di Bursa Efek Indonesia. Jurnal Akuntansi Indonesia, 12(2).

Jasmani, J. (2018). Pengaruh Kualitas Produk Dan Harga Terhadap Keputusan Pembelian Pada PT. Baja Mandiri Di Jakarta. Disrupsi Binis, 1(1).

Kartini Kartono (2011) Pemimpin dan Kepemimpinan, Jakarta: PT. Rajawaligrafindo Persada.

Keller dan Amstrong (2017) "Prinsip-prinsip Pemasaran". Edisi Kedua Belas". Jilid Satu. Jakarta: Erlangga.

Kevin Keller dan Amstrong (2017) Prinsip-prinsip Pemasaran, 
Edisi Kedua Belas, Jilid Satu, Jakarta: Erlangga.

Kharis, Ismu Fadli (2011). "Studi Mengenai Impulse Buying dalam Penjualan Online”. Semarang : Skripsi Universitas Diponegoro

Kotler \& Keller (2016) "Manajemen Pemasaran”. PT. Macaman Jaya Cemerlang. Jakarta.

Kotler (2016) "Manajemen Pemasaran”. Edisi Keempat belas, Jakarta: PT. Indeks.

Lupiyadi, Rambat (2016) Manajemen Pemasaran Jasa edisi 2 , Jakarta : Salemba Empat.

Lupiyoadi (2016) Manajemen Pemasaran Jasa, Edisi 4, Jakarta: Salemba Empat.

Mangkunegara, Anwar Prabu, 2008. "Manajemen Sumber Daya Manusia Perusahaan, cetakan pertama". Penerbit: Remaja Rosdakarya, Bandung

Mangkunegara, Prabu Anwar. (2016). Evaluasi Kinerja SDM. Cetakan ke tujuh, PT Refika Aditama: Bandung.

Nitisemito, Alek.S, (2010), Manajemen Personalia, Ghalia Indonesia, Jakarta.

Philip Kotler (2017) Manajemen Pemasaran, Edisi Keempat Belas, Jakarta: PT. Indeks.

Pranoto, P., Jasmani, J., \& Marayasa, I. N. (2019). Pelatihan Digital Marketing Untuk Peningkatan Perekonomian Anggota Karang Taruna Al Barkah Di Kampung Cicayur-Tangerang. Jurnal Pengabdian Dharma Laksana, 1(2), 250-258.

Pranoto, P., Jasmani, J., \& Marayasa, I. N. (2019). Pelatihan Digital Marketing Untuk Peningkatan Perekonomian Anggota Karang
Taruna Al Barkah Di Kampung Cicayur-Tangerang. Jurnal Pengabdian Dharma Laksana, 1(2), 250-258.

Prasada, D. (2019). Pengaruh Pemberian Kompensasi Dan Komitmen Organisasional Terhadap Turnover Intention Pada Karyawan Divisi Keperawatan Eka Hospital BSD. KREATIF: Jurnal Ilmiah Prodi Manajemen Universitas Pamulang, 7(1), 55-65.

Prasada, D., Sarwani, S., \& Catio, M. (2019). Pengaruh Kompensasi Dan Lingkungan Kerja Terhadap Kinerja Karyawan Pada PT. Mitra Adiperkasa, TBK. Jurnal Manajemen, Bisnis dan Organisasi (JUMBO), 3(3), 195-207.

Rao, Purba, (2012). "Measuring Consumer Perceptions Through Factor Analysis", The Asian.

Rivai Veithzal (2015) Manajemen Sumber Daya Manusia Untuk Perusahaan. Jakarta: PT Raja Grafindo Persada.

Rivai Veithzal (2015) Manajemen Sumber Daya Manusia Untuk Perusahaan. Penerbit PT Raja Grafindo Persada, Jakarta, 2010.

Santoso, Singgih (2015). "Menguasai Statistik Multivariat”. Jakarta: PT Elex Media Komputindo.

Sedarmayanti (2016) Manajemen Sumber Daya Manusia, Reformasi Birokrasi dan Manajemen Pegawai Negeri Sipil, Cetakan Kelima, Bandung: PT Refika Aditama.

Siagian, S (2007). Manajemen Sumber Daya Manusia. Jakarta: Bumi Aksara. 
Sinamo, J. (2011). Delapan Etos Kerja Profesional. Jakarta: Institut

Sudjana (2014) "Metode Statistika”, Bandung: Tarsido.

Sugiyono (2017), "Metode Penelitian Administrasi : dilengkapi dengan Metode $R \& D$ '. Bandung: Alfabeta.

Suhartanto (2014). "Metode Riset Pemasaran". Bandung: Alfabeta

Sunarsi, D. (2018). Buku Ajar: Seminar Perencanaan Sumber Daya Manusia. Tangerang Selatan: Asmoro Mediatama

Sunarsi, D. (2018). Pengembangan Sumber Daya Manusia Strategik \& Karakterisrik Sistem Pendukungnya : Sebuah Tinjauan. Jurnal Ilmiah MEA (Manajemen, Ekonomi, \& Akuntansi), 2(3), 178 - 194.

Sunarsi, D. (2019). Seminar Sumber Daya Manusia. Tangerang Selatan: Unpam Press

Supatmin, S., Septiani, F., \& Jasmani, J. (2018). Pelatihan Kewirausahaan Tanaman Sayur Mayur Dengan Teknik Hidroponik Untuk Meningkatkan Perekonomian Keluarga Pada MTS Insan Madani Di Desa Tegallega Rahong Hilir Cigudeg Bogor Barat Jawa Barat. Jurnal Pengabdian Dharma Laksana, 1(1), 141-151.
Susanti, N., \& Jasmani, J. (2020). The Influence of Product Quality and Service Quality on Customer Satisfaction at Mitra 10 in Depok. Jurnal Office, 5(2), 75-84.

Suwanto, S. (2019). Pengaruh Gaya Kepemimpinan Dan Lingkungan Kerja Terhadap Kinerja Karyawan Unit Telesales Pada PT BFI Finance Indonesia TBK. Jurnal Ekonomi Efektif, 1(2).

$\mathrm{T}$ Triyadi, U Ahidin, $\mathrm{J}$ Jasmani Jurnal Manajemen, Bisnis dan Organisasi (JUMBO), 2019. Pengaruh Promosi Dan Kualitas Pelayanan Terhadap Kepuasan Pelanggan Pada PT. Surya Karya Prima Di Jakarta.

Thoha. 2013. Kepemimpinan dan Manajemen. Jakarta : PT Raja Grafindo

Yuangga, K. D., Jasmani, J., Irmal, I., Supiyan, D., \& Rostikawati, D. (2020). Menumbuhkan Kebuasaan Hidup Cermat Dengan Memanfaatkan Celengan di Lingkungan Desa Cidokom Kecamatan Gunung Sindur. Jurnal Pengabdian Dharma Laksana, 2(2), 147152

Yukl. 2015. Kepemimpinan Dalam Organisasi (Edisi 7). Jakarta : Indeks 